\title{
MENENTUKAN MINIMUM SPANNING TREE DENGAN MENGGUNAKAN DETERMINAN
}

\author{
LAKSMI CHARINA THASYA, NARWEN \\ Jurusan Matematika, \\ Fakultas Matematika dan Ilmu Pengetahuan Alam, Universitas Andalas, \\ Kampus UNAND Limau Manis Padang, Indonesia. \\ email : laksmicharina7@gmail.com
}

\begin{abstract}
Abstrak. Terdapat beberapa metoda untuk mencari sebuah minimum spanning tree dalam graf terhubung dengan pembobotan. Diantaranya dengan menggunakan determinan submatriks non singular dari matriks insidensi graf yang diberikan. Pada tulisan ini akan dibahas tentang bagaimana menentukan minimum spanning tree dengan menggunakan determinan.

Kata Kunci: Spanning tree, Minimum spanning tree, Determinan dari matriks insidensi bobot sisi
\end{abstract}

\section{Pendahuluan}

Misalkan sebuah perusahaan berencana membangun jaringan komunikasi yang menghubungkan lima pusat komputer yang tersebar di berbagai kota. Setiap dua komputer terhubung dengan jalur telpon sewaan. Perusahaan menginginkan hanya ada satu lintasan yang menghubungkan setiap dua pusat komputer dan biaya pembangunan jaringan tersebut minimum. Model matematika yang dapat mewakili masalah ini adalah graf dengan pembobotan (weighted graphs).

Weight graphs adalah suatu graf tanpa sisi ganda dimana setiap sisinya berhubungan dengan suatu bilangan riil tak negatif yang menyatakan bobot sisi tersebut. Pada graf dengan pembobotan, titik (vertex) dapat mewakili pusat-pusat komputer yang terdapat di berbagai kota dan sisi (edges) mewakili jalur yang disewa, sedangkan bobot dari sisi mewakili biaya pembangunan jaringan. Jumlah bobot semua sisi disebut total bobot.Untuk menyelesaikan permasalahan tersebut dapat dilakukan dengan mencari semua spanning tree yang mempunyai total penjumlahan bobot sisi minimum. Tree yang demikian disebut dengan minimum spanning tree.

Dari permasalahan tersebut dikembangkan dan didapat adanya beberapa jalur yang memiliki biaya pembangunan jaringan yang sama. Sehingga, banyaknya minimum spanning tree yang dapat dibangun lebih dari satu. Untuk Mencari semua minimum spanning tree dapat dilakukan dengan cara memeriksa keterhubungan sisi pembentuk minimum spanning tree berdasarkan metode determinan submatriks non singular dari matriks insidensi graf yang diberikan. Masalah selanjutnya adalah berapa banyak minimum spanning tree yang dapat dibentuk dan sisi mana saja dari graf tersebut yang membentuk minimum spanning tree. 


\section{Tinjauan Teori}

Graf $G=(V, E)$ terdiri dari himpunan objek $V=\left\{v_{1}, v_{2}, \cdots, v_{n}\right\}, V \neq \phi$, yang disebut titik-titik (vertices) dan himpunan lainnya $E$ yang elemen-elemennya disebut sisi-sisi (edges).

Tree adalah graf terhubung yang sederhana yang tidak memuat cycle dan hanya ada satu lintasan diantara setiap pasang titiknya. Suatu graf $G$ adalah tree jika dan hanya jika dalam graf $G$ ada satu dan hanya satu lintasan yang menghubungkan setiap pasangan titik. Sebuah tree dengan $n$ titik mempunyai $n-1$ sisi. Sebuah graf $G$ dengan $n$ titik, $n-1$ sisi dan tidak ada cycle adalah graf terhubung. Suatu graf adalah sebuah tree jika dan hanya jika graf tersebut terhubung minimal. Jika graf $G$ adalah sebuah tree dengan $p$ titik dan $q$ sisi maka $p=q+1$.

Spanning tree adalah subgraf sederhana yang terhubung minimal yang tidak memuat cycle. Setiap graf terhubung paling sedikit mempunyai satu spanning tree. Graf terhubung $G$ adalah spanning tree jika dan hanya jika menambahkan sebuah sisi antara dua titik sebarang dalam $G$ akan membentuk tepat satu cycle.

\section{Matriks Representasi Graf}

(1) Matriks representasi graf tanpa Pembobotan Misalkan graf $G=(V, E)$ mempunyai $n$ titik dan $b$ sisi. Asumsikan $G$ graf sederhana dan berhingga.

(a) Matriks ketetanggaan (Adjacency Matriks).

Matriks ketetanggaan dari graf $G$ adalah matriks $X=\left[x_{i j}\right]$ berukuran $n \times n$ yang entri-entrinya adalah,

$x_{i j}= \begin{cases}1, & \text { jika terdapat sisi yang menghubungkan titik ke- } i \text { titik ke- } j ; \\ 0, & \text { jika tidak ada sisi yang menghubungkan titik ke- } i \text { dan titik ke- } j .\end{cases}$

(b) Matriks Insidensi (Incidence Matriks).

Misalkan pada graf $G$ diberikan arah sebarang, Titik-titik diberi nomor $i=$ $1,2, \cdots, n$ dan sisi $j=1,2, \cdots, b$ maka matriks insidensi dari graf $G$ adalah matriks $D=\left[x_{i j}\right]$ berukuran $n \times b$ yang entri-entrinya adalah,

$$
d_{i j}= \begin{cases}1, & \text { jika sisi ke- } j \text { arahnya keluar dari titik ke- } i \\ -1, & \text { jika sisi ke- } j \text { arahnya masuk pada titik ke- } i \\ 0, & \text { jika sisi ke- } j \text { tidak menempel pada titik ke- } i\end{cases}
$$

(2) Matriks representasi graf dengan Pembobotan

Graf $G(V, E)$ dikatakan graf dengan pembobotan, apabila ada fungsi bobot $w$ bernilai positif pada sisi-sisi dari graf $G$. Jadi $w\left(e_{i j}\right)$ adalah bobot sisi antara titik ke- $i$ dan titik ke- $j[8]$.

(a) Matriks bobot sisi

Matriks bobot sisi dari graf $G$ dengan pembobotan adalah matriks

$$
E=\left[x_{i j}\right]_{n \times n}
$$

yang entri-entrinya adalah :

$$
x_{i j}= \begin{cases}w\left(e_{i j}\right), & \text { jika } w\left(e_{i j}\right) \text { adalah bobot sisi antara titik ke- } i \text { dan ke- } j, \\ 0, & \text { jika tidak ada sisi yang terkait titik ke- } i \text { dan ke- } j .\end{cases}
$$


Matriks bobot sisi identik dengan matriks ketetanggaan dari graf $G$, akan tetapi bilangan 1 pada matriks ketetanggaan diganti dengan nilai fungsi bobot sisi yaitu $w\left(e_{i j}\right)$ untuk titik $v_{i}$ dengan $v_{j}$.

(b) Insidensi bobot sisi

Misalkan pada graf berbobot $G$ diberikan arah sebarang, titik-titik diberi nomor $i=1,2,3, \cdots, n$ dan sisi-sisi diberi nomor $j=1,2,3, \cdots, b$,maka matriks insidensi bobot sisi dari graf $G$ adalah matriks

$$
D=\left[d_{i j}\right]_{n \times b}
$$

yang entri-entrinya adalah,

$$
d_{i j}= \begin{cases}w\left(e_{i j}\right), & \text { jika sisi ke- } j \text { arahnya keluar dari titik ke- } i, \\ w\left(e_{i j}\right), & \text { jika sisi ke- } j \text { arahnya masuk pada titik ke- } i, \\ 0, & \text { jika sisi ke- } j \text { tidak menempel pada titik ke- } i\end{cases}
$$

Matriks insidensi bobot sisi ini diperoleh dengan merubah matrik insidensi, yaitu \pm 1 diganti dengan $\pm w\left(e_{i j}\right)$. Dengan menghapus salah satu baris sebarang dari matriks insidensi bobot sisi $D$ diperoleh matriks insidensi sisi tereduksi $A$.

\section{Determinan untuk graf dengan pembobotan}

Dengan alasan yang sama dengan graf tanpa pembobotan, maka suatu himpunan $H$ dari $n-1$ sisi dari graf $G$ dengan pembobotan merupakan spanning tree jika dan hanya jika $\operatorname{det} M(H) \neq 0$, dimana $M(H)$ adalah submatriks berukuran $(n-1) \times(n-1)$ dari matriks insidensi bobot sisi tereduksi $A$ yang kolom-kolomnya berkorespondensi dengan sisi-sisi $H$. Dengan demikian jelaslah bahwa untuk sebarang spanning tree $H$, $\operatorname{det} M(H)= \pm \prod$, dimana $\prod$ merupakan perkalian bobotbobot sisi di dalam tree. Determinan ini dapat digunakan untuk mengidentifikasi minimum spanning tree yang terdapat didalam graf $G$.

Teorema 4.1. [8] Suatu spanning tree dalam graf $G$ dengan pembobotan mempunyai penjumlahan bobot sisi yang minimum jika dan hanya jika spanning tree tersebut mempunyai perkalian bobot sisi yang minimum.

Bukti. $(\Leftarrow)$ Misalkan $S$ dan $T$ adalah spanning tree dari graf $G$. Andaikan $T$ mempunyai perkalian bobot sisi minimum tetapi bukan penjumlahan bobot sisi minimum. Misalkan $S$ sebuah tree dengan penjumlahan bobot sisi minimum. Maka spektrum bobot sisi dari $T$ dan $S$ tidak sama. Misalkan $k$ bobot sisi terkecil sehingga untuk semua sisi yang bobotnya lebih besar atau sama dengan $k$ maka $T$ dan $S$ mempunyai spektrum bobot sisi tidak sama. Akibatnya, $T$ mempunyai lebih kecil atau sama banyak sisi yang bobotnya $k$ dari pada $S$. Jadi haruslah $T$ mempunyai lebih kecil atau sama banyaknya sisi bobot nya $k$ dari pada $S$. Misalkan $T(k)$ adalah himpunan sisi-sisi $T$ bobotnya lebih kecil atau sama dengan $k$. Dalam hal ini, anggota $T(k)$ dapat dipilih semuanya dengan menggunakan algoritma Kruskal. Karena spektrum dari sisi yang bobotnya $k$ belum digunakan semuanya, maka paling sedikit ada satu sisi $e \in G$ yang bobotnya $k$ tidak membentuk cycle dengan 
$T(k)$. Sisi e yang demikian akan membentuk sebuah cycle dengan T. Karena itu, ada beberapa sisi pada cycle tersebut yang bobotnya lebih besar dari pada bobot sisi $e$. Ganti sisi bobot nya lebih besar dari bobot $e$ dengan sisi $e$, sehingga diperoleh sebuah tree dengan perkalian bobot sisi lebih kecil dari perkalian bobot sisi $T$. Hal ini kontradiksi dengan hipotesis bahwa $T$ merupakan perkalian bobot sisi minimum. Jadi jika $T$ mempunyai perkalian bobot sisi minimum, maka $T$ mempunyai penjumlahan bobot sisi minimum.

$(\Rightarrow)$ Andaikan $T$ mempunyai penjumlahan bobot sisi minimum tetapi bukan perkalian bobot sisi minimum. Misalkan $S$ sebuah tree dengan perkalian bobot sisi minimum. Maka spektrum bobot sisi dari $T$ dan $S$ tidak sama. Misalkan $k$ bobot sisi terkecil sehingga untuk semua sisi yang bobotnya lebih besar atau sama dengan $k$ maka $T$ dan $S$ mempuyai spektrum bobot sisi tidak sama. Akibatnya, dengan cara yang sama dengan sebelumnya, maka $S$ mempunyai lebih kecil atau sama banyaknya sisi yang bobotya $k$ dari pada $T$. Misalkan $S(k)$ adalah himpunan sisi $S$ yang bobotnya lebih kecil atau sama dengan $k$. Kemudian anggota $S(k)$ dapat dipilih semuanya dengan menggunakan algoritma Kruskal. Karena spektrum dari sisi yang bobotnya $k$ belum digunakan semuanya, maka paling sedikit ada satu sisi $e \in G$ yang bobotnya $k$ tidak membentuk cycle dengan $S(k)$. Sisi e yang demikian akan membentuk sebuah cycle dengan $S$. Karena itu, ada beberapa sisi pada cycle tersebut yang bobotnya lebih besar dari bobot $e$. Ganti sisi yang bobotnya lebih besar dari bobot $e$ dengan sisi $e$, sehingga diperoleh sebuah tree dengan perkalian bobot sisi lebih kecil dari perkalian bobot sisi $S$. Hal ini kontradiksi dengan hipotesis bahwa $S$ adalah perkalian bobot sisi minimum. Jadi jika $T$ mempunyai penjumlahan bobot sisi minimum, maka $T$ mempunyai perkalian bobot sisi minimum.

Teorema 4.2. [8] Misalkan $H$ adalah himpunan dari $n-1$ sisi dari graf $G$ dengan pembobotan, dan $M(H)$ adalah submatrik berukuran $(n-1) \times(n-1)$ dari A. Maka $H$ adalah sebuah minimum spanning tree jika dan hanya jika $|\operatorname{det} M(H)|$ adalah minimal diantara semua determinan submatriks non singular berukuran $(n-1) \times$ $(n-1) \operatorname{dari} A$.

Bukti. $(\Rightarrow)$ Misalkan $H$ adalah minimum spanning tree pada graf $G$. Maka $H$ mempunyai $n$ titik dan $n-1$ sisi dari $G$ dan $H$ mempunyai penjumlahan bobot sisi minimum. Menurut Teorema 4.1. maka $H$ mempunyai hasil perkalian bobot sisi minimum, ini berarti $|\operatorname{det} M(H)|$ adalah minimal diantara semua determinan submatriks non singular berukuran $(n-1) \times(n-1)$ dari $A$.

$(\Leftarrow)$ Misalkan $|\operatorname{det} M(H)|$ adalah minimal diantara semua determinan submatriks non singular berukuran $(n-1) \times(n-1)$ dari $A$. Ini berarti bahwa hasil perkalian bobot sisi dari $H$ adalah minimum. Menurut Teorema 4.1., maka $H$ juga mempunyai penjumlahan bobot sisi minimum. Dengan demikian $H$ adalah minimum spanning tree pada graf $G$.

\section{Kesimpulan}

Pada tugas akhir ini diperoleh bagaimana cara mencari minimum spanning tree pada suatu graf menggunakan determinan matriks insidensi bobot sisi tereduksi 
dari graf yang diberikan.

Suatu spanning tree dalam graf $G$ dengan pembobotan mempunyai penjumlahan bobot sisi minimum jika dan hanya jika mempunyai perkalian bobot sisi minimum. Untuk mencari perkalian bobot sisi minimum terlebih dahulu dicari matriks ketetanggaan dan matriks insidensi dari graf $G$ kemudian matriks tersebut direduksi. Lalu cari banyaknya kemungkinan untuk membentuk spanning tree. Dari semua kemungkinan tersebut dicari determinan dari submatriksnya. Kemudian didapat determinan dari submatriks tersebut. Jika $\operatorname{det} M(H) \neq 0$ maka didapatlah spanning tree dari graf tersebut. Sub matriks dengan determinan terkecil adalah minimum spanning tree. Kemudian cari jumlah pembobotan dari spanning tree tersebut. Maka didapatlah minimum spanning tree dari graf $G$.

\section{Daftar Pustaka}

[1] Alan Tucker, Applied Combinatorics, $3^{\text {rd }}$ ed., John Wiley and Sons, Inc., Canada, 1995.

[2] Anton, H. dan Rorres, C .1991. Ajabar Linear Elementer. Edisi Kelima. Erlangga, Jakarta.

[3] Bondy, J.A dan Murty, U.S.R. 1976. Graph Theory with Application. London: The Macmillan Press LTD.

[4] Deo, Narshing. 1986. Graph Theory with Application to Engineering and Computer Science. Prentice Hall. New Delhi.

[5] Fletcher, P., H. Hoyle dan C. W. Patty. 1991. Foundations of Discrete Mathematics. PWS-KENT Publishing Company. Buston.

[6] Frank Harary, Graph Theory, Addison-Wesly Publishing, London, 1969.

[7] Narshing Deo, Graph Theory with Application to Engineering and Computer Science, Prentice Hall, New Delhi, 1986.

[8] Narwen. Suatu Metoda untuk Menentukan Semua Minimum Spanning Tree dalam Suatu Graf. Tesis S-2 Matematika. ITB. Bandung, 2002.

[9] Norman Biggs, Algebraic Graph Theory, $2^{\text {nd }}$ ed., Cambridge University Press, New York, 1993.

[10] Perrin Wright, 1997, Counting and Constructing Minimal Spanning Trees, Bulletin of the Institute of Combinatorics and Its Applications 21:65-76.

[11] Perrin Wright, 2000, On Minimal Spanning Tree and Determinants. Mathematics Magazine 73 (1) : $1-28$. 